\title{
Bacillus thuringiensis kurstaki strains produce vegetative insecticidal proteins (Vip 3) with high potential
}

\author{
Ebru Güney, Aysun Adıgüzel, Zihni Demirbağ and Kazım Sezen*
}

\begin{abstract}
Bacillus thuringiensis (Bt) produces vegetative insecticidal proteins (Vip) during its vegetative growth stage. Vip3 proteins have a significant role in insecticidal activity of this bacterium. Each new bacterial isolate may encode Vip with different significance. The Vip protein coding by vip genes of two Bt strains (BnBt and MnD) with high insecticidal activity was characterized in this study. Polymerase chain reaction (PCR)-based screening for Vip genes of these Bt isolates expressed the detected Vip gene and tested the protein for insecticidal activity against the cotton leafworm, Spodoptera littoralis larvae. As a result of the screening tests, Vip3 genes were determined in MnD and BnBt isolates. Vip3 genes of both isolates were expressed and confirmed by $90 \mathrm{kDa}$ proteins. Partially purified and trypsin-activated protein samples of $\mathrm{BnBt}$ and $\mathrm{MnD}$ isolates were tested against the second instar larvae of $\mathrm{S}$. littoralis. The results showed that the highest insecticidal activity of the Vip3 proteins of BnBt and MnD was $86.66 \%$ and $83.33 \%$ mortality in 10 days, respectively. The median lethal concentrations $\left(\mathrm{LC}_{50}\right)$ of $\mathrm{BnBt}$ and $\mathrm{MnD}$ were determined as 41.860 and $55.154 \mathrm{ng} / \mu \mathrm{l}$, respectively. The results suggest that Vip3 protein is effective for preventing resistance in various insect-pest species. The expressed proteins may be utilized as a biopesticide against nocuous insects.
\end{abstract}

Keywords: Bacillus thuringiensis kurstaki, Insecticidal activity, Microbial control, Vip3 gene

\section{Background}

In most of the developed and developing countries, Bacillus thuringiensis (Bt) preparations are used commercially against pests belong mainly to orders Lepidoptera, Diptera, and Coleoptera. Bt toxins are highly specific for their pests and have great importance as an alternative to chemical insecticides all over the world. Despite the wide success of Cry proteins in agricultural insect control, increased insect resistance and narrow insecticidal spectrum threaten the longterm sustainability of $B t$ technology (Kurt et al. 2005; Sezen et al. 2007 and 2008). Therefore, it is necessary to identify new insecticidal proteins with different characteristics other than known Cry proteins, i.e., vegetative insecticidal proteins (Vip, etc.). Towards this aim, several studies have been conducted to

\footnotetext{
* Correspondence: sezen@ktu.edu.tr

Department of Biology, Faculty of Science, Karadeniz Technical University, Trabzon, Turkey
}

identify and characterize new Vips from new Bt isolates which exist in various habitats (Chakroun 2015). There are many lepidopteran species which are resistant to Cry proteins and Spodoptera littoralis (Boisd.) is one of the most important of these pests. In addition, it has been reported that Vip3 proteins against this pest have been highly effective (Chakroun 2015; Chakroun et al. 2016; Van Frankenhuyzen and Nystrom 2018).

Vip proteins are a family of insecticidal proteins secreted by different Bacillus species (Bhalla et al. 2005). They are classified into four families Vip1, Vip2, Vip3, and Vip4, according to their sequence similarity. Vip1 and Vip2 have activity against coleopteran and homopteran insects; however, Vip3 has insecticidal activity against lepidopteran pests (Warren 1997; Crickmore et al. 2017).

Because Bt kurstaki isolates have Vip3 gene, the present study aimed to investigate Vip3 gene in two different Bt kurstaki isolates ( $\mathrm{MnD}, \mathrm{BnBt})$ expressing Vip3 
gene and test the protein for its insecticidal activity against $S$. littoralis larvae.

\section{Materials and methods}

\section{Bacillus thuringiensis isolates and growth conditions}

Local B. thuringiensis kurstaki strains ( $\mathrm{MnD}$ and $\mathrm{BnBt}$ ) obtained from the culture collection at Department of Biology, Faculty of Science, Karadeniz Technical University, Turkey, and B. thuringiensis kurstaki HD-1 strain (positive control) obtained from Bacillus Genetic Stock Center were used in this study (Kati et al. 2005, 2007; Sezen et al. 2010). Bt isolates were grown in a nutrient agar (NA; Merck) and Luria Bertani media at $30^{\circ} \mathrm{C}$ (for $1 \mathrm{l} \mathrm{LB} ; 10 \mathrm{~g}$ tryptone, $5 \mathrm{~g} \mathrm{NaCl}, 5 \mathrm{~g}$ yeast extract).

\section{Insect colonies}

Spodoptera littoralis was grown in the Microbiology Laboratory, Karadeniz Technical University, Trabzon, Turkey, under controlled conditions of $25 \pm 2{ }^{\circ} \mathrm{C}, 60 \pm$ 5\% RH, and L16:D8 h. S. littoralis originated from a standardized culture line. Larvae were reared on semisynthetic diet (266.5 g dried bean, $4 \mathrm{~g}$ ascorbic acid, $2.5 \mathrm{~g}$ methyl 4 hydroxybenzoate, $1.25 \mathrm{~g}$ sorbic acid, $0.5 \mathrm{~g}$ B vitamin, $3 \mathrm{~g}$ wheat germ, $35 \mathrm{~g}$ yeast extract, $14 \mathrm{~g}$ agar).

\section{Detection of Vip3 gene by polymerase chain reaction}

Total DNA was extracted as explained earlier (Ferrandis et al. 1999). For the screening of the Vip3 gene, degenerate primers were used (Hernández-Rodríguez et al. 2009). Polymerase chain reaction (PCR) was prepared in a final volume of $50 \mu \mathrm{l}$. The PCR mixtures included $3 \mu \mathrm{l}$ of the DNA template, $1.25 \mathrm{U}$ of Taq DNA polymerase (New England BioLabs), $5 \mu \mathrm{l}$ of $10 \times$ reaction buffer, $3 \mu \mathrm{l}$ $1.5 \mathrm{mM} \mathrm{MgCl}, 1 \mu \mathrm{l} 10 \mathrm{mM}$ of each dNTP, and $1 \mu \mathrm{l} 10$ $\mathrm{mM}$ primers for Vip3 gene screening. The PCR conditions were as follows: $5 \mathrm{~min}$ denaturation at $95^{\circ} \mathrm{C}$, followed by 35 cycles of denaturation at $95^{\circ} \mathrm{C}$ for $1 \mathrm{~min}$, annealing at $45^{\circ} \mathrm{C}$ for $1 \mathrm{~min}$, and extension at $72^{\circ} \mathrm{C}$ for $2 \mathrm{~min}$. Final extension was carried out at $72{ }^{\circ} \mathrm{C}$ for 10 min. The products were separated by electrophoresis in $1 \%$ agarose gel.

\section{Cloning and sequencing of Vip3 gene}

The amplified Vip3 DNA fragment was purified, using the NucleoSpin Extract DNA Purification Kit (from Macherey-Nagel), ligated with pGEM-T cloning vector (from Promega) using T4 DNA ligase enzyme, and transformed into Escherichia coli JM101 cells. The clones were selected on LB plates containing ampicillin $(50 \mathrm{mg} / \mathrm{ml}), X-G a l(40 \mathrm{mg} / \mathrm{ml})$, and IPTG $(24 \mathrm{mg} / \mathrm{ml})$. The Vip3 gene was analyzed and compared to the updated GenBank data by using BLAST program (http:// www.ncbi.nlm.nih.gov/blast).

\section{Purification of Vip3 proteins}

Culture of $B$. thuringiensis kurstaki isolates (BnBt, $M n D$ )

$B$. thuringiensis isolates were re-inoculated to a 0.1 $\mathrm{OD}_{600} \mathrm{~nm}$ from an overnight culture on a Teriffic $(12 \%$ tryptone, $2.4 \%$ yeast extract, $0.04 \%$ glycerol, $0.17 \mathrm{M}$ $\mathrm{KH}_{2} \mathrm{PO}$, $0.72 \mathrm{M} \mathrm{K}_{2} \mathrm{HPO}_{4}$ ) liquid medium to determine the bacterial growth phase and vegetative phase and were maintained at $30^{\circ} \mathrm{C}$ in a shaking incubator. Measurements were taken at $\mathrm{OD}_{600} \mathrm{~nm}$ with samples taken at specific time intervals for $36 \mathrm{~h}$, and the vegetative phase was determined by plotting the data on the graph.

\section{Isolation of Vip 3 proteins from cultured supernatants}

Bacterial cultures grown for $24 \mathrm{~h}$ were centrifuged at $12.000 \mathrm{~g}$ for $10 \mathrm{~min}$ at $4{ }^{\circ} \mathrm{C}$, and supernatants containing Vip3 proteins were collected (Sattar et al. 2008).

\section{Ammonium sulfate precipitation}

Ammonium sulfate $\left[\left(\mathrm{NH}_{4}\right)_{2} \mathrm{SO}_{4}\right]$ precipitation method (REF) was followed to precipitate the protein from the culture supernatant. First of all, solid ammonium sulfate was added to the bacterial supernatant at $60 \%$ saturation (Sattar et al. 2008). Ammonium sulfate was added to the supernatant slowly at $4{ }^{\circ} \mathrm{C}$ by mixing on a magnetic stirrer. Precipitation was followed by centrifugation at $10.000 \mathrm{rpm}$ for $10 \mathrm{~min}$ at $4{ }^{\circ} \mathrm{C}$. After centrifugation, the pellets were resolved by using $1 \mathrm{ml}$ of $100 \mathrm{mM}$ pH 7.5 Tris- $\mathrm{HCl}$ buffer.

The ammonium sulfate precipitation was subjected to overnight dialysis against $20 \mathrm{mM}$ pH 7.5 Tris- $\mathrm{HCl}$ buffer to remove especially the salts and small molecules. Following dialysis, the samples were centrifuged at the highest speed for $10 \mathrm{~min}$ to allow the degradation of the proteins.

\section{lon-exchange chromatography}

A column of $50 \mathrm{~cm}$ in length and $1.5 \mathrm{~cm}$ in diameter was used for ion-exchange chromatography. For this purpose, Q-Sepharose (anion exchanger), an anionic ion exchanger, was used in this process. Tris-HCI buffer (20 $\mathrm{mM} \mathrm{pH} \mathrm{8)} \mathrm{was} \mathrm{used} \mathrm{as} \mathrm{the} \mathrm{mobile} \mathrm{phase.} \mathrm{The} \mathrm{gasses} \mathrm{of}$ the column material and all buffers used in the experiment were taken in a vacuum pump and then slowly filled into the collar using a pasteurized pipette. After filling, the column was equilibrated with $500 \mathrm{ml}$ of TrisHCI buffer. The extract was passed through the column to allow the contained proteins to be attached to the column packing material. Subsequently, $50 \mathrm{ml}$ of buffer was passed through the column to remove proteins that were not attached to the column. The salt $(\mathrm{NaCl})$ content of the column was then increased from 0 to $0.6 \mathrm{M}$. A 200 $\mathrm{ml} \mathrm{NaCl}$ gradient bridge was used for this. The buffer flow rate was set to $1 \mathrm{ml} / \mathrm{min}$, and the fractions from the column were collected in glass tubes to be $3.5 \mathrm{ml}$. 
The fractions obtained were run on 12\% SDS-PAGE. The determined tubes containing protein extract were combined and selected for purity on SDS-PAGE. After completion of the SDS-PAGE run, the gels were stained with fast silver staining technique. The gel image was transferred to the computer using a scanner.

\section{Estimation of the protein}

The amount of protein was determined according to the Bradford method (Bradford 1976). Bovine serum albumin (BSA) was used as standard in the calibration curve prepared. The prepared standards and samples were transferred onto 96-well microplates, and measurements were made at $595 \mathrm{~nm}$, using a UV-visible spectroscopy system (Bio-rad).

\section{Trypsin activation of Vip3 proteins}

Partially purified Vip3 proteins were activated by commercial trypsin $(10 \%)$ at $37^{\circ} \mathrm{C}$ for $2 \mathrm{~h}$.

\section{Determination of insecticidal activities of Vip3 proteins}

The second instar larvae of $S$. littoralis were used to test the activity of partially purified and trypsin-activated Vip3 proteins of Bt kurstaki isolates (BnBt, MnD). Protein samples were prepared at the concentrations of 10, $25,50,100$, and $200 \mathrm{ng} / \mu \mathrm{l}$ from both Vip3 proteins. In the experiments, water and $\mathrm{NaCl}$ were used as negative controls. Samples containing Vip3 proteins of BnBt and $\mathrm{MnD}$ isolates were spread with $10 \mu \mathrm{l}$ of sample on the 1 $\mathrm{cm}^{2}$ of lettuce leaf for testing on each one larva of $S$. littoralis. The concentrations of toxin samples were applied per insect. Larvae were starved for $4 \mathrm{~h}$ before application. For each concentration of Vip3 protein, 30 larvae were placed in test vessels one by one, and tests were repeated three times. Biotests were carried out at $25 \pm 2{ }^{\circ} \mathrm{C}$ and $60 \% \mathrm{RH}$. Larval mortality was followed up to 10 days and corrected for control mortality, using Abbott's formula (Abbott 1925).

The data were subjected to ANOVA and subsequently to LSD. The lethal concentrations ( $\mathrm{LC}_{50}$ and $\mathrm{LC}_{90}$ ) were estimated by probit regression analysis (Finney 1971). Statistical analyses were performed using SPSS 20.0 software.

\section{Results and discussion}

\section{Molecular analysis of Vip3 gene from local Bt isolates}

The Vip3 gene was amplified by polymerase chain reaction (PCR) and electrophoresed on a 1\% agarose gel. As a result, $1.621 \mathrm{bp}$ of Vip3 gene of both isolates was detected. The presence of the Vip3 gene in the HD-1 isolate used as a control was also observed. The presence of Vip3 gene was detected in Bt kurstaki BnBt and MnD strains (Fig. 1).

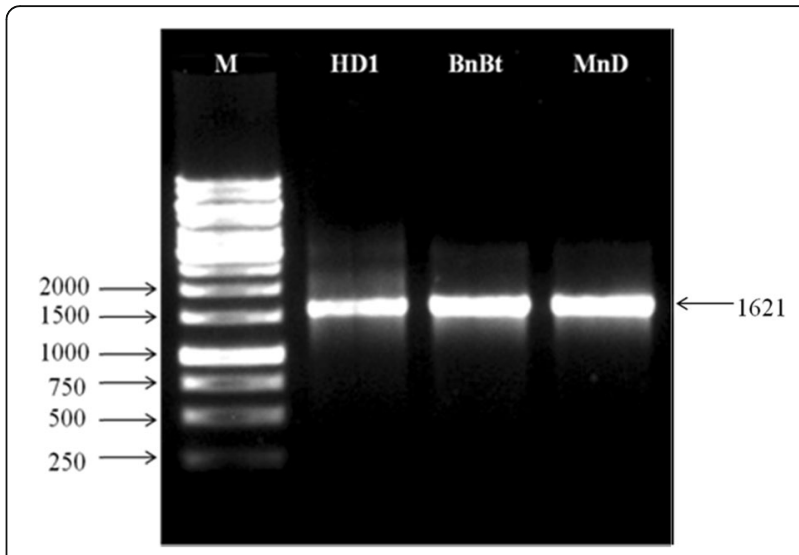

Fig. 1 The presence of Vip3 gene of Bacillus thuringiensis kurstaki $B n B t$ and $M n D$ strains and HD-1 strain as a positive control

Nucleotide sequence accession number

The sequence of the gene encoding the Vip3 protein was deposited in the GenBank database (http://www. ncbi.nlm.nih.gov) under the accession number MH318013 for BnBt and MH318014 for MnD.

\section{Isolation of Vip3 proteins of B. thuringiensis kurstaki strains}

After purification and SDS-PAGE analysis of Vip3 proteins, a band of $\sim 90 \mathrm{kDa}$ was detected for Vip3 proteins (Fig. 2).

\section{Determination of the potential of the obtained Vip3 proteins on S. littoralis larvae}

The highest larval mortalities were observed by the application of $200 \mathrm{ng} / \mu \mathrm{l}$ concentration. The mortalities were determined on the 10th day as 86.66 and $83.33 \%$ for $\mathrm{BnBt}$ and $\mathrm{MnD}$ isolates, respectively (Fig. 3). In the negative control, $13.3 \%$ of mortality rate was observed. The median lethal concentrations $\left(\mathrm{LC}_{50}\right)$ of Vip3 of $\mathrm{BnBt}$ and $\mathrm{MnD}$ were determined as 41.860 and $55.154 \mathrm{ng} / \mu \mathrm{l}$, respectively. $\mathrm{LC}_{90}$ of $\mathrm{BnBt}$ and $\mathrm{MnD}$ were determined as 367.204 and $420.978 \mathrm{ng} / \mu \mathrm{l}$, respectively (Table 1 ).

Overlapping of fiducial limits of $\mathrm{LC}_{50}$ s means insignificant differences among the tested strains at 5\% level of probability.

During the vegetative growth phase of $B t$, it has been found that some strains produce medium-secreted proteins called Vip that show insecticidal activity against pests (Donovan et al. 2001; Milne et al. 2008).

Analysis of the local $B t$ collections may help to illuminate the dispersion of Vip genes and the stock of novel Vip genes. To date, there are a lot of studies on Vip genes of $B t$ in the literature; however, there is no study regarding this issue in the Eurasia region (Milne et al. 2008). So, this study has a unique value as the first investigation for the presence of Vip3 gene in local $B t$ 


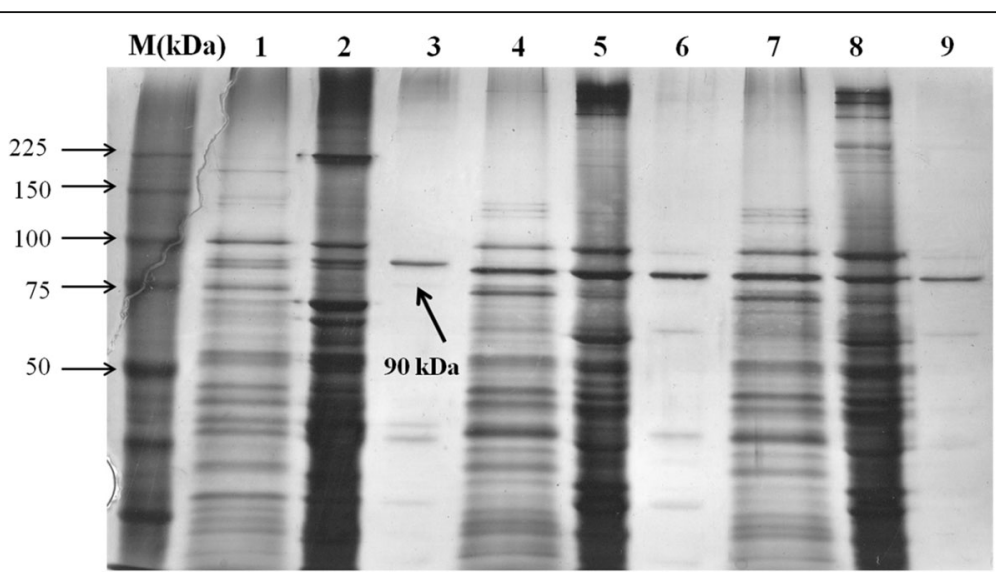

Fig. 2 SDS-PAGE analysis of partially purified Vip3 proteins from Bacillus thuringiensis isolates. 1, 4, and 7 indicate crude extract of HD-1 as positive control, BnBt, and MnD strains. 2, 5, and 8 indicate 60\% ammonium sulfate precipitation of HD-1, BnBt, and MnD supernatants. 3, 6, and 9 indicate ion-exchange column chromatography

kurstaki (BnBt, $\mathrm{MnD})$ strains and for the application of Vip3A proteins against larvae of $S$. littoralis.

PCR studies were initially performed to determine the presence of Vip genes in the local Bt kurstaki (BnBt, $\mathrm{MnD}$ ) isolates and in standard/control strain HD-1. For this purpose, Vip1 (585 bp), Vip2 (845 bp), and Vip3 (1621 bp) gene regions were partially amplified and sequenced as indicated in earlier studies (HernándezRodríguez et al. 2009). According to the obtained results, the Bt kurstaki $(\mathrm{BnBt}, \mathrm{MnD})$ isolates contained only the Vip3 gene.

Hernández-Rodríguez et al. (2009) conducted a study to identify known Vip genes and potentially identify new Vip genes in the $B t$ collection of 507 strains. The screening of the Vip genes was performed by primers designed from the appropriate regions in the Vip gene families. By screening, 507 strains detected 54 (10.7\%) strains of Vip1 gene, 46 (9.1\%) strains of Vip2 gene, and 248 strains detected Vip3 (48.9\%) gene. They then used the PCR-RFLP method to identify the different Vip genes of the same family.

As a result of this study, the presence of $\sim 90 \mathrm{kDa}$ protein was observed by SDS-PAGE analysis. These results were consistent with the results of earlier studies (Bhalla et al. 2005; Mesrati et al. 2005a, 2005b; Sattar et al. 2008).

As a result of bioassays, 86.6 and $83.3 \%$ of insecticidal activities of the Vip3 proteins were obtained from the $\mathrm{BnBt}$ and $\mathrm{MnD}$ isolates, respectively, at the concentration of $200 \mathrm{ng} / \mu \mathrm{l}$. Lethal concentrations $\left(\mathrm{LC}_{50}\right.$ and $\mathrm{LC}_{90}$ ) of $\mathrm{BnBt}$ and $\mathrm{MnD}$ were determined as $41.860,55.154 \mathrm{ng} / \mu \mathrm{l}$ and $367.204,420.978 \mathrm{ng} / \mu \mathrm{l}$, respectively.

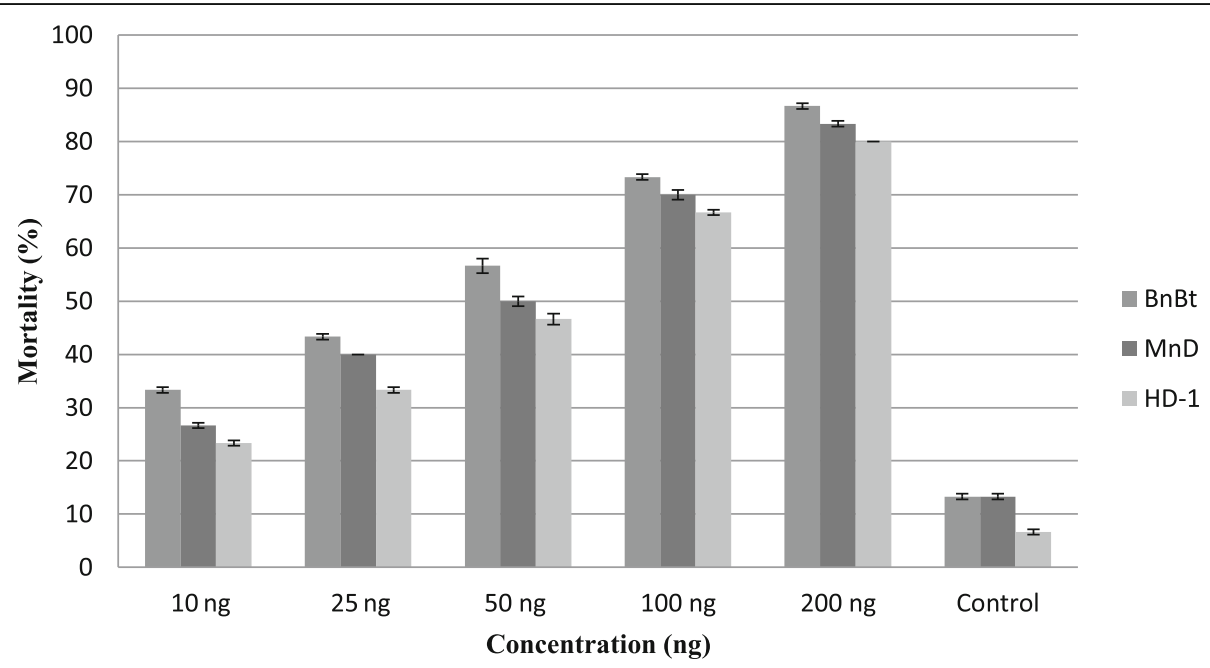

Fig. 3 Potential of Vip3 proteins of BnBt and MnD versus second instar larvae of Spodoptera littoralis 
Table $1 L_{50}$ and $L C_{90}$ values of Vip3 proteins of $B n B t$ and $M n D$ against Spodoptera littoralis larvae

\begin{tabular}{|c|c|c|c|c|c|}
\hline Strains & $\mathrm{LC}_{50}(\mathrm{FL}, 95 \%)$ & Slope \pm SE & $\mathrm{LC}_{90}(\mathrm{FL}, 95 \%)$ & $d f$ & $x^{2}$ \\
\hline $\mathrm{BnBt}$ & $41.860 \mathrm{ng} / \mu \mathrm{l}(22.355-78.383)$ & $1.365 \pm 0.139$ & 367.204 ng/Ml (196.102-687.592) & 3 & 0.972 \\
\hline $\mathrm{MnD}$ & $55.154 \mathrm{ng} / \mu \mathrm{l}(30.455-99.882)$ & $1.454 \pm 0.132$ & $420.978 \mathrm{ng} / \mu \mathrm{l}(232.460-762.381)$ & 3 & 0.989 \\
\hline HD-1 & $68.066 \mathrm{ng} / \mu \mathrm{l}(34.596-133.917)$ & $1.258 \pm 0.150$ & $714.561 \mathrm{ng} / \mu \mathrm{l}(363.188-1405.878)$ & 3 & 0.983 \\
\hline
\end{tabular}

LSD multiple comparison test $(p<0.05)$

$F L$ fiducial limit, $S E$ standard error, $d f$ degree of freedom, $X^{2}$ chi-square

Activity of Vip3A-activated toxins at $2.5 \mu \mathrm{g} / \mathrm{cm}^{2}$ against S. littoralis larvae after 10 days was $100 \%$ mortality (Escudero et al. 2014). In another study, $\mathrm{LC}_{25}, \mathrm{LC}_{50}$, $\mathrm{LC}_{75}$, and $\mathrm{LC}_{90}$ values for the purified proteins were $118.9,142.4,170.5$, and $200.5 \mu \mathrm{g} / \mathrm{ml}$ against the first larval instar of $S$. littoralis, respectively (El-Ghareeb et al. 2012). Sattar et al. (2008) conducted a two-step ionexchange chromatography in order to obtain Vip3 protein as a single band. In the same study, crude protein extracts obtained from the supernatants of different $B t$ isolates were bioassayed against Agrotis ipsilon, Helicoverpa armigera, and S. littoralis larvae with Vip3 proteins, partially purified by ion-exchange chromatography. Deaths were observed for 7 days and mortality rates ranged between 11 and $95 \%$ versus the first instar neonate larvae with $25 \mu \mathrm{g} / \mathrm{ml}$ crude protein extract. The $B t$ isolate with the highest toxicity was selected, the Vip3 protein was purified by a two-step DEAE-Sephacel anion exchange column, and $\mathrm{LC}_{50}$ values were determined by testing against lepidopteran pest larvae. Comparing the present results to the results of Vip3 activity of other $B t$ strains described by other authors showed very similar effects.

\section{Conclusion}

The results of the study confirm the significance of continuous exploration of new $B t$ strains from different ecological regions of the world. In addition, the Vip3A protein was responsible for the toxicity of the $B t$ isolates $\mathrm{BnBt}$ and $\mathrm{MnD}$ culture supernatants. Also, gene may be effective for preventing resistance in various insect-pest species. This protein may be used to develop a biopesticide.

\section{Acknowledgements}

We thank Dr. Umut Toprak for help in rearing the insect colonies.

\section{Authors' contributions}

EG and AA performed all the experiments. ZD and KS conceived and designed all the experiments. All authors read and approved the final manuscript.

\section{Funding}

This research was supported by Karadeniz Technical University-BAP (project number: 6846).

\section{Availability of data and materials}

The dataset(s) supporting the conclusions of this article is (are) included within the article (and its additional file(s)).
Ethics approval and consent to participate

Not applicable.

\section{Consent for publication}

Not applicable.

\section{Competing interests}

The authors declare that they have no competing interests.

Received: 27 August 2019 Accepted: 14 October 2019

Published online: 04 December 2019

\section{References}

Abbott WS (1925) A method of computing the effectiveness of insecticide. J Econ Entomol 18:265-267

Bhalla R, Dalal M, Panguluri SK, Jagadish B, Mandaokar AD, Singh AK, Kumar PA (2005) Isolation, characterization and expression of a novel vegetative insecticidal protein gene of Bacillus thuringiensis. FEMS Microbiol Lett 243:467-472

Bradford MM (1976) A rapid and sensitive method for the quantitation of microgram quantities of protein utilizing the principle of protein-dye binding. Anal Biochem 72:248-254

Chakroun M (2015) Biochemical and molecular study of the Bacillus thuringiensis vegetative insecticidal proteins (Vip3A) mode of action in Spodoptera species. PhD Thesis, Universitat de Valencia, Spain.

Chakroun M, Banyuls N, Bel Y, Escriche B, Ferré J (2016) Bacterial vegetative insecticidal proteins (Vip) from entomopathogenic bacteria. Microbiol Mol Biol Rev 80(2):329-350

Crickmore N, Zeigler DR, Schnepf E, van Rie J, Lereclus D, Baum J, Bravo A, Dean DH (2017). Bacillus thuringiensis toxin nomenclature [online]. Website http:// www.lifesci.sussex.ac.uk/Home/Neil_Crickmore/Bt/. Accessed 25 May 2017.

Donovan WP, Donovan JC, Engleman JT (2001) Gene knockout demonstrates that vip3A contributes to the pathogenesis of Bacillus thuringiensis toward Agrotis ipsilon and Spodoptera exigua. J Invertebr Pathol 78:45-51

El-Ghareeb DK, Osman GH, El Baz AF (2012) Isolation, cloning, and overexpression of vip3Aa gene isolated from a local Bacillus thuringiensis. Biocont Sci Technol 22:11-21

Escudero IR, Banyuls N, Bel Y, Maeztu M, Escriche B, Muñoz D, Caballero P, Ferré J (2014) A screening of five Bacillus thuringiensis Vip3A proteins for their activity against lepidopteran pests. J Invertebr Pathol 117:51-55

Ferrandis MD, Juárez-Pérez VM, Frutos R, Bel Y, Ferré J (1999) Distribution of cryl, cryll and cryV genes within Bacillus thuringiensis isolates from Spain. Syst Appl Microbiol 22:179-185

Finney DJ (1971) Probit analysis. Cambridge University Press, New York, p 333 Hernández-Rodríguez CS, Boets A, Van Rie J, Ferré J (2009) Screening and identification of vip genes in Bacillus thuringiensis strains. J Appl Microbiol 107:219-225

Kati H, Sezen K, Belduz AO, Demirbag Z (2005) Characterization of a Bacillus thuringiensis subsp. kurstaki strain isolated from Malacosoma neustria L. (Lepidoptera: Lasiocampidae). Biologia 60(3):301-305

Kati H, Sezen K, Nalcacıoglu R, Demirbag Z (2007) A highly pathogenic strain of Bacillus thuringiensis serovar kurstaki on the lepidopteran pests. J Microbiol 45(6):553-557

Kurt A, Ozkan M, Sezen K, Demirbag Z, Ozcengiz G (2005) Cry3Aa11: a new Cry3Aa delta-endotoxin from a local isolate of Bacillus thuringiensis. Biotechnol Lett 27(15):1117-1121

Mesrati LA, Tounsi S, Jaoua S (2005b) Characterization of a novel vip3-type gene from Bacillus thuringiensis and evidence of its presence on a large plasmid. FEMS Microbiol Lett 244:353-358 
Mesrati LA, Tounsi S, Kamoun F, Jaoua S (2005a) Identification of a promoter for the vegetative insecticidal protein-encoding gene vip3LB from Bacillus thuringiensis. FEMS Microbiol Lett 247:101-104

Milne R, Liu Y, Gauthier D, Van Frankenhuyzen K (2008) Purification of Vip3Aa from Bacillus thuringiensis HD-1 and its contribution to toxicity of HD-1 to spruce budworm (Choristoneura fumiferana) and gypsy moth (Lymantria dispar) (Lepidoptera). J Invertebr Pathol 991:66-172

Sattar S, Biswas PK, Hossai MA, Maiti MK, Sen SK, Basu A (2008) Search for vegetative insecticidal proteins (VIPs) from local isolates of Bt effective against lepidopteran and homopteran insect pests. J Biopesticides 1:216-222

Sezen K, Demir I, Demirbag Z (2007) Identification and pathogenicity of entomopathogenic bacteria from common cockchafer, Melolontha melolontha L. (Col., Scarabaeidae). New Zealand J Crop Horti Sci 35:79-85

Sezen K, Kati H, Muratoglu H, Demirbag Z (2010) Characterization and toxicity of Bacillus thuringiensis strains from hazelnut pests and fields. Pest Manag Sci 66(5):543-548

Sezen K, Kati H, Nalcacioglu R, Muratoglu H, Demirbag Z (2008) Identification and pathogenicity of bacteria from European shot-hole borer, Xyleborus dispar Fabricius (Coleoptera: Scolytidae). Ann Microbiol 58:173-179

Van Frankenhuyzen K, Nystrom C (2018) The Bacillus thuringiensis toxin specificity database [online]. Website http://www.glfc.cfs.nrcan.gc.ca/bacillus. Accessed 25 May 2017.

Warren GW (1997) Vegetative insecticidal proteins: novel proteins for control of corn pests. In: Carozzi NB, Koziel M (eds) Advances in insect control, the role of transgenic plants. Taylors \& Francis Ltd, London, pp 109-121

\section{Publisher's Note}

Springer Nature remains neutral with regard to jurisdictional claims in published maps and institutional affiliations.

\section{Submit your manuscript to a SpringerOpen ${ }^{\odot}$ journal and benefit from:}

- Convenient online submission

- Rigorous peer review

- Open access: articles freely available online

High visibility within the field

- Retaining the copyright to your article

Submit your next manuscript at $\boldsymbol{\nabla}$ springeropen.com 